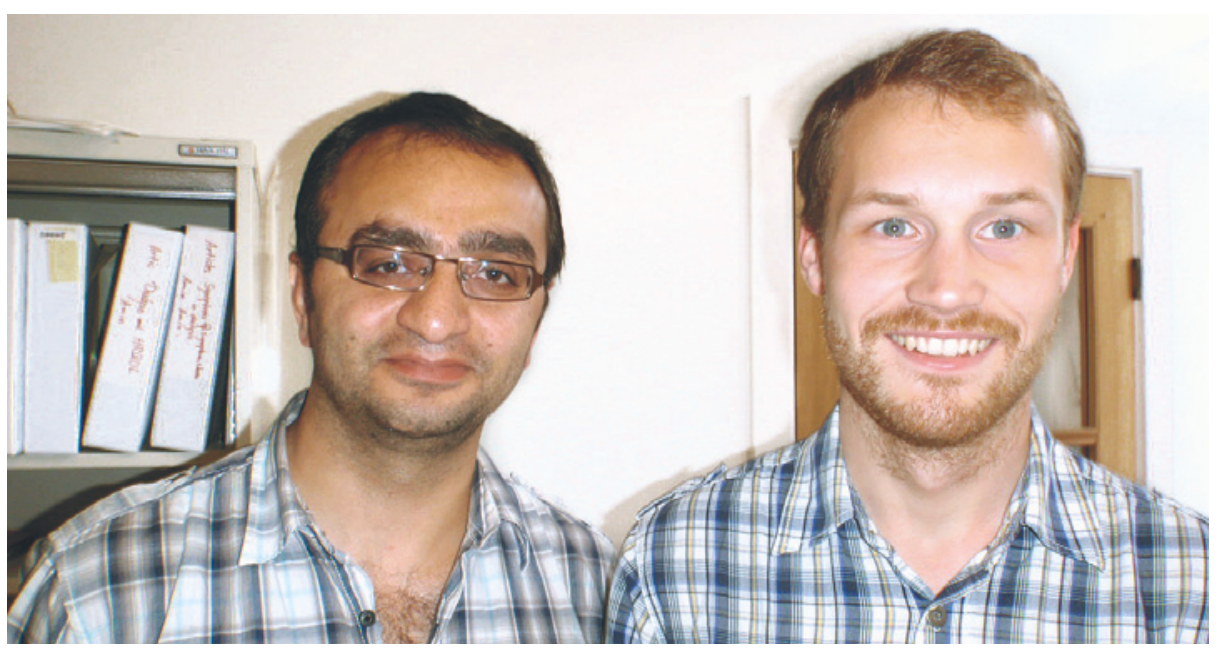

Amin Amro (til venstre) og Fredrik Brekke er to av forfatterne bak artikkelen om dialysepasienters søvnkvalitet. Foto Viera Stubnova

MIN FøRSTE PUBLIKASJON

\title{
Dialysepasienter sliter med søvnproblemer
}

Dårlig søvnkvalitet og depresjon er utbredt blant norske dialysepasienter.

Pasienter med dialysekrevende kronisk nyresvikt har høy grad av komorbiditet, og som gruppe har disse pasientene betydelig redusert livskvalitet i forhold til den generelle befolkningen. De fleste går til hemodialyse 2-4 ganger i uken med 2-5 timers varighet per sesjon. Studier fra andre land har vist at søvnproblemer er blant de mest plagsomme symptomene hos dialysepasientene.

I en norsk multisenterstudie med 301 dialysepasienter fra ti ulike sykehus ble søvnproblemer, søvnkvalitet og depresjonssymptomer kartlagt ved bruk av internasjonalt anerkjente spørreskjemaer (1). $75 \%$ rapporterte om dårlig søvnkvalitet, $22 \%$ om uttalt søvnighet på dagtid og nesten $30 \%$ hadde symptomer på depresjon. Depresjon var assosiert med dårlig søvnkvalitet. De som sov dårlig, hadde en klart dårligere livskvalitet enn de med god søvn. Til sammenlikning har studier i normalbefolkningen vist at $10-15 \%$ sliter med søvnproblemer. Forskerne konkluderer med at alle dialysepasienter rutinemessig bør screenes for symptomer på søvnproblemer og depresjon med enkle spørreskjemaer, slik at de som sliter, kan fanges opp og tilbys behandling.

- Som gruppe skiller norske dialysepasienter seg fra dialysepasienter $i$ andre land - bl.a. er andelen menn høyere, gjennomsnittlig BMI-verdi lavere og utsiktene for rask nyretransplantasjon langt bedre. Derfor har det vært et behov for å kartlegge søvn- og livskvalitet også hos norske dialysepasienter, sier Fredrik Brekke, som er førsteforfatter på artikkelen. Brekke er forskerlinjestudent ved Universitetet i Oslo, og dette er hans første publikasjon.

- Vi håper med denne studien at det blir mer oppmerksomhet rundt livskvalitet og søvnplager hos pasienter i dialyse. Det finnes i dag ikke retningslinjer for konkrete behandlingstiltak for dialysepasienters søvnproblemer, men både kognitiv atferdsterapi og hypnotika kan være aktuelt, sier Brekke.

\section{Nyremedisinsk forskergruppe}

Studien er gjennomført i regi av Nyremedisinsk forskningsgruppe ved Oslo universitetssykehus, Ullevål, under ledelse av professor Ingrid Os. Forskningsgruppen har flere interesseområder og er involvert i både kliniske studier for å forstå patogenesen ved hypertensjonsutvikling, i store epidemiologiske studier der man ser på sammenhengen mellom nyre- og hjertesykdom og i studier for å kartlegge livskvaliteten til dialysepasienter. Den omtalte artikkelen er skrevet på bakgrunn av en større undersøkelse der man ser på ulike aspekter ved dialysepasienters livskvalitet, inkludert symptombyrde, søvn, angst og depresjon. I tillegg til Brekke og Os er artikkelforfatterne Amin Amro, Tone Brit Hortemo Østhus, Toril Dammen og Bård Waldum.

\section{Hanne Støre Valeur}

hanne.store.valeur@legeforeningen.no

Tidsskriftet

\section{Litteratur}

1. Brekke FB, Amro A, Hortemo Østhus TB et al. Sleep complaints, depression and quality of life in Norwegian dialysis patients. Clin Nephrol 2013, 80: 88-97.
Ordforklaringer

Helserelatert livskvalitet (health-related quality of life): En egenvurdering av livskvalitet basert på fysiske, psykiske og sosiale dimensjoner. Oftest vurdert gjennom spørreskjema. Søvnkvalitet (quality of sleep): Vurdering av egen søvn gjennom spørreskjemaer hvor bl.a. søvneffektivitet, søvnighet på dagtid, innsovningstid, antall timer søvn og bruk av sovemedisin inngår. 